\title{
COMBINING ABILITY OF GRAIN SORGHUM INBRED LINES GROWN DURING OFF-SEASON $^{1}$
}

\author{
LUDMILLA RIBEIRO DA ROCHA GOMES ${ }^{2}$, CÍCERO BESERRA DE MENEZES ${ }^{3}$, GUSTAVO ANDRÉ SIMON*, \\ ALESSANDRO GUERRA DA SILVA ${ }^{4}$, ANTONIO JOAQUIM BRAGA PEREIRA BRAZ ${ }^{4}$
}

\begin{abstract}
The expansion of sorghum as a succession crop, after soybean, has demanded the development of new inbred lines by the breeding programs. The first step in the selection process consists of evaluating the performance per se of the inbred lines or of their hybrid combination. The purpose of this study was to determine the combining ability of sorghum inbred lines under different environment conditions of the crop production areas. The trials were carried out in the second season of 2017, under no-tillage system, in four environments, Rio Verde, Sete Lagoas, Teresina and Sinop. Thirty hybrids, resulting from the crosses of six fertility restoration lines $(\mathrm{R})$ with five male-sterile lines (A) were evaluated. A randomized complete block design with three replicates was used in all experiments. The characteristics evaluated were flowering, plant height and grain yield. The environment significantly influenced the estimates of general and specific combining ability, which suggests that both effects, additive and dominant, are important in the control of these characters. The restoring lines GI.1 and G1.2 contributed to increasing the grain yield of their hybrids by over $650 \mathrm{~kg} \cdot \mathrm{ha}^{-1}$. Among the male-sterile lines, the best for grain yield were GII.1 and GII.4 with contribution above $450 \mathrm{~kg} \cdot \mathrm{ha}^{-1}$ in the hybrids in which they participate. The hybrid combinations GI.5xGII.3 and GI.1xGII.2 stood out with potential to obtain high grain yield, associating positive aspects of the other characteristics.
\end{abstract}

Keywords: Sorghum bicolor. Diallel crosses. Parent selection. Plant breeding.

\section{ANÁLISE DIALÉLICA DE LINHAGENS DE SORGO GRANÍFERO EM CULTIVO NA SEGUNDA SAFRA}

RESUMO - Com a expansão do plantio de sorgo como cultura de sucessão na segunda safra, os programas de melhoramento precisam ampliar a criação de novas linhagens, visando à produção de híbridos de alto desempenho. O primeiro passo para o processo de seleção consiste na avaliação do desempenho per se das linhagens ou de suas combinações híbridas. O presente trabalho objetivou estimar a capacidade combinatória de linhagens de sorgo granífero em diferentes condições ambientais em plantios na segunda safra. Os ensaios foram conduzidos em sistema de plantio direto, em quatro ambientes: Rio Verde, Sete Lagoas, Teresina e Sinop. Foram avaliados trinta híbridos resultantes dos cruzamentos de seis linhagens restauradoras da fertilidade (R) com cinco linhagens macho-estéreis (A). Foi empregado o delineamento experimental em blocos casualizados, com três repetições. As características avaliadas foram dias para o florescimento, altura das plantas e produtividade de grãos. O ambiente influenciou significativamente nas estimativas de capacidade geral e específica de combinação, e estas sugerem haver importância dos efeitos aditivos e dominantes no controle desses caracteres. As linhagens restauradoras GI.1 e G1.2 contribuíram para aumentar a produtividade de seus híbridos em mais $650 \mathrm{~kg} \cdot \mathrm{ha}^{-1}$. Entre as linhagens macho estéreis as melhores para rendimento de grãos foram GII.1 e GII.4 com contribuição acima de $450 \mathrm{~kg}$.ha ${ }^{-1}$ nos híbridos em que participaram. As combinações híbridas GI.5xGII.3 e GI.1xGII.2 se destacaram por apresentarem potencial de obterem médias altas de produtividade de grãos, associando aspectos favoráveis de dias para o florescimento e altura das plantas.

Palavras-chave: Sorghum bicolor. Cruzamentos dialélicos. Seleção de genitores. Melhoramento de plantas.

\footnotetext{
${ }^{*}$ Corresponding author

${ }^{1}$ Received for publication in $10 / 22 / 2019$; accepted in 07/13/2020.

Paper extracted from the master's dissertation of the first author.

${ }^{2}$ Universidade de Rio Verde, Rio Verde, GO, Brazil; ludmilla_rrg@hotmail.com - ORCID: 0000-0001-9335-1480.

${ }^{3}$ Embrapa Milho e Sorgo, Sete Lagoas, MG, Brazil; cicero.menezes@embrapa.br - ORCID: 0000-0001-9437-6946.

${ }^{4}$ Departament of Agronomy, Universidade de Rio Verde, Rio Verde, GO, Brazil; simon@unirv.edu.br - ORCID: 0000-0001-6935-6580, silvaag@yahoo.com.br - ORCID: 0000-0002-9556-0312, braz@unirv.edu.br - ORCID: 0000-0001-5442-3891.
}

Rev. Caatinga, Mossoró, v. 33, n. 4, p. 888 - 897, out. - dez., 2020 


\section{INTRODUCTION}

Sorghum is grown predominantly in the Midwest, Southeast and Northeast regions of Brazil, with the states of Goiás, Minas Gerais, Bahia and Mato Grosso being the largest producers (CONAB, 2019). Sorghum stands out in these regions for its ability to adapt to different environments and for showing satisfactory performance in situations where the volume and frequency of rainfall tend to be fluctuating or even limiting to other species (ALMEIDA FILHO et al., 2010).

Thus, research in the field of genetic improvement of sorghum allows the development of genotypes more adapted to these producing regions, in which favorable characters such as hybrids with high yield, earliness and plant height ideal for harvest are associated, and that meet farmers' and beneficiary companies' requirements (KUMAR et al., 2011; TARDIN et al., 2013).

The choice of the most promising genotypes to be used as parents in crossbreeding is one of the crucial steps in the breeding program, as it allows the majority of efforts to be dedicated to segregating populations potentially capable of providing superior progenies (VENCOVSKY; BARRIGA, 1992). In this case, the diallel breeding technique assists the breeder in choosing parents based on their genetic values and, mainly, considering their ability to combine, resulting in promising hybrids (MENEZES et al., 2017).

From the diallel analysis, it is possible to estimate the general and specific combining abilities (CRUZ; CARNEIRO; REGAZZI, 2014). In addition, this analysis elucidates the nature, magnitude and genetic actions involved in the expression of the evaluated characteristics, which are relevant for establishing routines for improving sorghum crop (PRAKASH et al., 2010).

Additive and non-additive effects of genes in controlling grain sorghum grain yield among other traits have been reported (MAKANDA et al., 2010; MENEZES et al., 2017). Grain yield is due to the linear additive effects of production components and the relative contribution of these characters can vary, depending on environmental conditions and crop management (TADESSE; TESSO; EJETA, 2008). Estimates of general combining ability and specific combining ability for days to flowering, plant height and thousand-grain weight varied considerably between sowing dates and places (MAHDY; ALI; MAHMOUD, 2011).

Given the above, the objective of this work was to generate information regarding the influence of the environment on the combining ability of grain sorghum strains under the different environmental conditions of the crop production areas.

\section{MATERIAL AND METHODS}

The study was conducted using six fertility restoring strains (R), represented by the acronyms GI.1: 9503062, GI.2: 9503086, GI.3: CMSXS1111, GI.4: SC 1080, GI.5: TX 2903, GI.6: CMSXS180R, and five male-sterile lines (A) that were represented by the acronyms GII.1: CMSXS1008A, GII.2: CMSXS1009A, GII.3: CMSXS1006A, GII.4: CMSXS1014A and GII.5: ATF14A, belonging to Embrapa Milho e Sorgo improvement program, located in Sete Lagoas - MG. The five lines A and six lines $\mathrm{R}$ were crossed in a $5 \times 6$ partial diallel scheme, obtaining 30 hybrids.

The trials were carried out in the succession crop of 2017, under no-tillage system, in four states: in the experimental area of the University of Rio Verde, in the city of Rio Verde - GO (871 m altitude, $17^{\circ} 47^{\prime} 14^{\prime \prime} \mathrm{S}$ and $50^{\circ} 57^{\prime} 38^{\prime \prime} \mathrm{W}$ ), with soil classified as Latossolo Vermelho distrófico (Oxisol), with climate type Aw, which receives the name of tropical climate; at the Embrapa Milho e Sorgo experimental station, located in Sete Lagoas - MG (767 m altitude, $19^{\circ} 27^{\prime} 57^{\prime \prime} \mathrm{S}$ and $44^{\circ} 14^{\prime} 49^{\prime \prime} \mathrm{W}$ ), with soil classified as Latossolo Vermelho distrófico and dominant climate of the type Cwa, humid mesothermal; at the Embrapa Meio Norte experimental station in Teresina - PI (61.0 m altitude, $05^{\circ} 02^{\prime} 8.6^{\prime \prime} \mathrm{S}$ and $42^{\circ}$ 47' 7.4" W), with soil classified as Argissolo Vermelho-Amarelo distrófico (Ultisol), Aw-type climate and characterized as dry, mega-thermal subhumid; and at the Embrapa Agrossilvipastoril experimental station in Sinop - MT (384 m altitude, $11^{\circ} 52^{\prime} 27^{\prime \prime} \mathrm{S}$ and $55^{\circ} 30^{\prime} 22^{\prime \prime} \mathrm{W}$ ), with soil classified as Latossolo Vermelho-Amarelo distrófico (Oxisol), Aw type, tropical climate. Soil classification was established according to EMBRAPA (2013) and the climate according to Köppen's classification, and climatic data are presented in Figure 1.

A randomized block design with three replicates was used in all locations. The experimental plots consisted of two rows of $5.0 \mathrm{~m}$ in length, spaced $0.50 \mathrm{~m}$ apart. The manual sowing of the experiments was performed in March 2017, maintaining the final population of approximately 180 thousand plants per hectare after thinning. Phytosanitary management, in all locations, was carried out according to the requirements of the crop and the needs observed in sample analysis. The experiments were harvested in July 2017.

The days to flowering characteristic was evaluated considering the period of emergence until anthesis of approximately $50 \%$ of the panicles. Plant height was measured, from the collar to the apex of the panicle, considering a sample of ten plants per plot. Grain yield was obtained from the harvest of the plot's grains, with values extrapolated to $\mathrm{kg} \mathrm{ha}^{-1}$ 
and corrected to $13 \%$ moisture.

The data was subjected to individual analysis of variance, with homogeneity of residual variances being verified by the ratio of the highest and lowest mean square of the residual $(<7: 1)$, thus allowing the joint analysis of variance of the tests to be carried out (BANZATTO; KRONKA, 2006).

The statistical model adopted for the joint analysis of variance, considering all experiments,

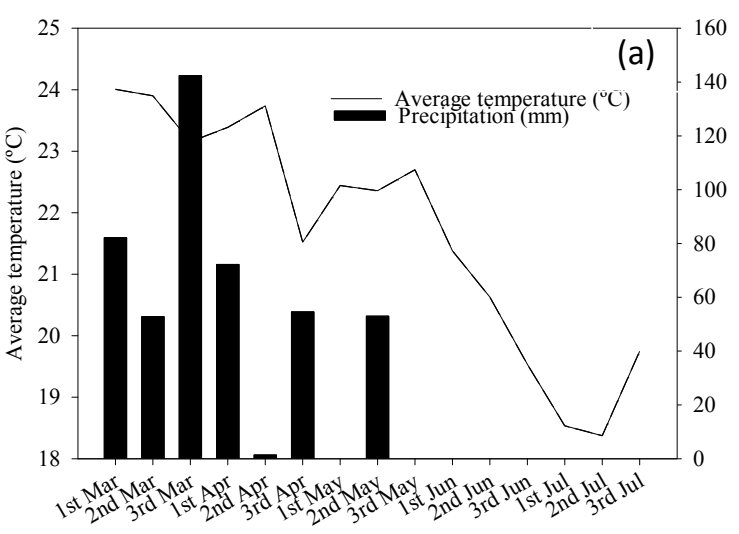

Ten days

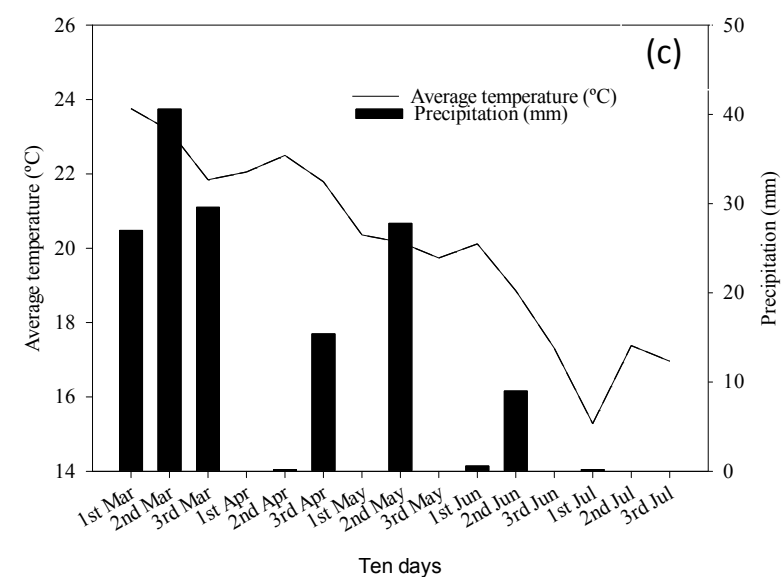

Figure 1. Rainfall and average air temperature in Rio Verde (a), Sinop (b), Sete Lagoas (c) and Teresina (d) during the succession crop of 2017. Source: INMET automatic stations.

The diallel analyses were performed according to the method IV of Griffing (1956), which allows estimating the effects of general combining ability (GCA) and specific combining ability (SCA), of partial diallels using only the F1 generation, according to the statistical model: $Y_{i j}=m$ $+g_{i}+g_{j}+s_{i j}+e_{i j}$, where $Y_{i j}$ : average observed value of the hybrid combination (ij) or the parent $(i=j)$; $m$ :

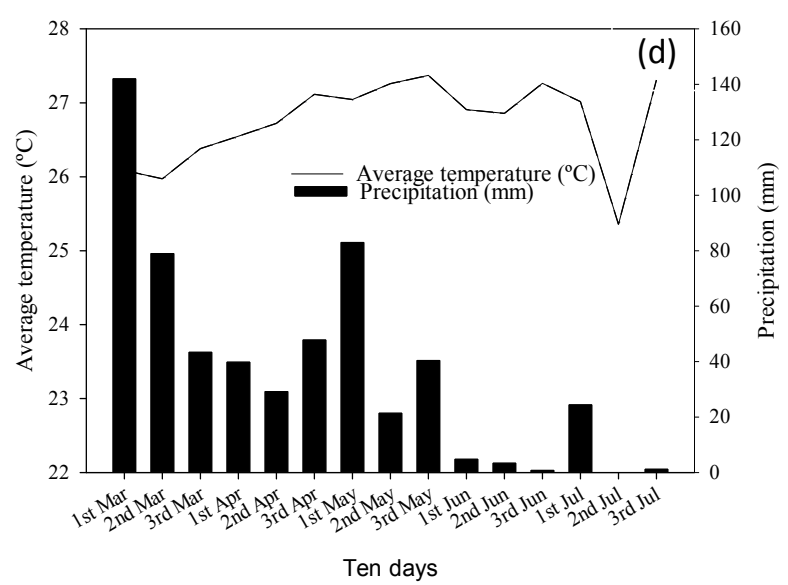

was: $Y_{i j k}=\mu+B_{k(A j)}+G_{i}+A_{j}+G_{i A j}+\varepsilon_{i j k}$; where $B_{k}$ (Aj) is the random effect of block $\mathrm{k}$ in environment $\mathrm{j}$; $\mathrm{G}_{\mathrm{i}}$ is the fixed effect of $\mathrm{i}$-th treatment; $\mathrm{A}_{j}$ is the random effect of the $j$-th environment; $G_{i A j}$ is the random effect of the interaction between genotype $i$ with the environment $\mathrm{j}$; and $\varepsilon_{\mathrm{ijk}}$ is the random effect of the experimental error observed in the ijk plot; $\varepsilon \mathrm{ij}$ $\sim \operatorname{NID}(0, \sigma 2)$.

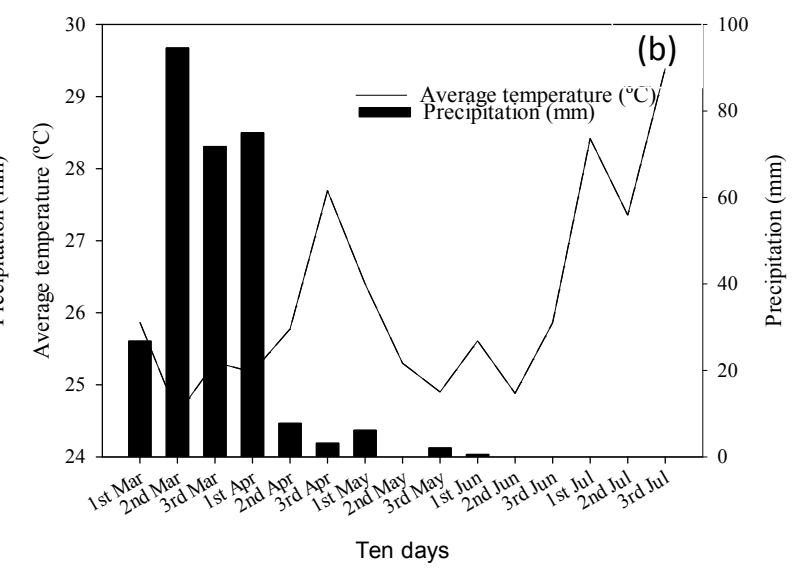

general average; $g_{i}$ and $g_{j}$ : effects of the general combining ability of the $\mathrm{i}$-th and the $\mathrm{j}$-th parents, respectively; $s_{\mathrm{ij}}$ : effect of specific combining ability for crosses between parents of order $\mathrm{i}$ and $\mathrm{j}$; $\mathrm{e}_{\mathrm{ij}}$ : experimental error. The analyses were performed using the computer program GENES (CRUZ; CARNEIRO; REGAZZI, 2014). 


\section{RESULTS AND DISCUSSION}

In the joint analysis of variance, a significant difference was observed between the hybrids for all the characteristics evaluated, thus confirming the presence of genetic variability between the parents, used in the partial diallel, and the hybrids originated from them (Table 1). The interaction between hybrids $\mathrm{x}$ environments ( $\mathrm{HxE}$ ) was significant for all characteristics, indicating that hybrids responded differently to environmental variations. Thus, the importance of environmental influence is emphasized, which reinforces the need to evaluate hybrid combinations in various places to estimate the parameters of GCA and SCA.
The effects of GCA I ( $\mathrm{R}$ strains) were significant for all traits, showing differences between the strains in the contribution of the characters. The effects of GCA II (A strains) were significant for plant height and grain yield, and not for flowering. For GCA II x E, there were significant effects, except for yield. The SCA x E interaction was not significant for plant height and grain yield. These results suggest that the effects of GCA and SCA, in general, responded differently to environmental variations, highlighting the importance of considering the different determining factors in the behavior of genotypes in relation to additive and dominant gene actions.

Table 1. Summary of the joint analysis of variance for days to flowering (FL), plant height (PH) and grain yield (GY), referring to the evaluation of 30 hybrid combinations from partial diallel crossing.

\begin{tabular}{ccccc}
\hline SV & DF & \multicolumn{3}{c}{ Mean squares } \\
\cline { 3 - 5 } & 29 & FL (days) & PH $(\mathrm{cm})$ & $\mathrm{GY}^{\left(\mathrm{kg} \mathrm{ha}^{-1}\right)}$ \\
\hline Hybrids (H) & 5 & $39.52^{* *}$ & $1188.18^{* *}$ & $12.34^{* *}$ \\
GCA GI $^{1}$ & 4 & $119.82^{*}$ & $3210.25^{* *}$ & $20.85^{* *}$ \\
GCA GII $^{2}$ & 20 & $13.84^{\mathrm{ns}}$ & $1738.83^{* *}$ & $27.71^{* *}$ \\
SCA $^{3}$ & 3 & $24.58^{* *}$ & $572.53^{* *}$ & $7.14^{* *}$ \\
Environments (E) & 87 & $4867.89^{* *}$ & $65475.88^{* *}$ & $43.59^{* *}$ \\
H x E & 15 & $13.74^{* *}$ & $134.41^{* *}$ & $1.43^{*}$ \\
GCA GI x E & 12 & $31.30^{* *}$ & $296.04^{* *}$ & $2.38^{* *}$ \\
GCA GII x E & $21.03^{* *}$ & $232.91^{* *}$ & $1.70^{\mathrm{ns}}$ \\
SCA x E & 60 & $7.89^{* *}$ & $74.31^{\mathrm{ns}}$ & $1.13^{\mathrm{ns}}$ \\
Residual & 200 & 4.49 & 69.79 & 1.02 \\
\hline CV (\%) & & 3.33 & 6.88 & 24.28 \\
\hline
\end{tabular}

* and ** significant at 5 and $1 \%$ probability, respectively, by the $\mathrm{F}$ test; ns not significant.

1GCA GI General Combining Ability of group 1; 2 GCA GII General Combining Ability of group 2; SCA Specific Combining Ability.

The superiority of the values of the mean squares of the GCA over those of the SCA (Table 1) is indicative of the greater importance of additive gene variability over non-additive (CRUZ; CARNEIRO, REGAZZI, 2014). In the present work, the effects of GCA were far superior to the effects of $\mathrm{SCA}$, proving that the evaluation of the performance of parental lines per se is important for sorghum. The mean square of the GCA of males (GI) was higher than that of females (GII), for days to flowering and plant height, showing greater variance of the restoring strains. For days to flowering, this variability is important, as planting in the second crop requires earlier hybrids, and the $\mathrm{R}$ strains may show greater selection gain.

Greater variability of restorative strains was expected, compared to male-sterile strains, for grain yield, since in sorghum breeding programs the ease of crossing and selection in restorative strains is greater than in male-sterile strains. The time to obtain male-sterile strains is twice that of restorative strains, because the former needs to be sterilized to be used as parents of hybrids (SANTOS; CASELA; WAQUIL, 2005; ROONEY, 2012). The production of sorghum hybrids is carried out by crossing a line A (male-sterile) with a line $\mathrm{R}$ (fertility restorer). For multiplication of the male-sterile strain, another strain called B (fertility maintainer) is required. Therefore, in the sorghum breeding program after obtaining line B, it needs to be retro crossed with line A for six generations, which basically doubles the time to obtain the male-sterile line.

For grain yield, the mean squares of GCA I and GCA II were similar and also higher than that of 
SCA. Other works with sorghum also show the importance of GCA in relation to SCA for characteristics of grain yield and flowering of plants (KENGA; ALABI; GUPTA, 2004; MENEZES et al., 2014).

A parent's GCA estimates provide indicators of its potential to generate superior strains. A low estimate of the GCA, positive or negative, indicates that the average of one parent crossing with the other does not differ from the general average of the crosses. On the other hand, a high estimate of the GCA indicates that the average is higher or lower than the general average, this generates information about the concentration of predominant genes with additive effects (MENEZES et al., 2014).

Among the six restorative strains of grain sorghum (Group I), the GCA values that most contributed to the reduction of the cycle were GI.1,
GI.2, GI.3 and GI.5 in Rio Verde, GI.1, GI.3 and GI.5 in Sete Lagoas, GI.3, GI.4, GI.5 in Sinop and GI.3 and GI.5 in Teresina. Conversely, the strains GI.4 and GI.6 in Rio Verde, GI.2 GI.4 and GI.6 in Sete Lagoas, GI.1, GI.2 and GI.6 in Sinop and GI.1, GI.2, GI.6 in Teresina showed an allelic frequency with an action to increase the cycle until flowering (Table 2)

The male-sterile strains (Group II) that contributed to reducing the cycle were GII.1 in all environments, GII.2 and GII.5 in Sinop and Teresina, GII.3 in Rio Verde, and GII.4 in Sete Lagoas. This suggests that the magnitudes of gene actions can be influenced by the environment, making it possible to define different improvement strategies depending on the desired location to evaluate the new genotypes.

Table 2. Estimates of the general combining ability (GCA) of groups I and II (gi and gi) for days to flowering, in 30 hybrid combinations resulting from partial diallel crossing, in Rio Verde-GO, Sete Lagoas-MG, Sinop-MT and Teresina-PI.

\begin{tabular}{lccccc}
\hline Parents & Rio Verde & Sete Lagoas & Sinop & Teresina & Averages \\
\hline GI.1 & & GI - Fertility-restorer male & parents (Strain R) & & \\
GI.2 & -0.45 & -0.86 & 2.02 & 2.09 & 0.70 \\
GI.3 & -1.37 & 1.28 & 1.9 & 0.83 & 0.66 \\
GI.4 & -0.99 & -1.86 & -0.18 & -0.81 & -0.96 \\
GI.5 & 2.47 & 0.66 & -2.22 & -0.33 & 0.15 \\
GI.6 & -0.93 & -2.08 & -3.16 & -2.93 & -2.27 \\
GII.1 & 1.25 & 2.84 & 1.62 & 1.15 & 1.72 \\
GII.2 & -0.83 & GII - Male-sterile female parents (Strain A) & & -0.2 \\
GII.3 & 0.07 & -0.39 & -0.26 & -1.07 & -0.15 \\
GII.4 & -0.48 & 0.66 & -0.26 & 0.1 & 0.10 \\
GII.5 & 1.06 & 0.76 & 0.01 & 2.36 & 0.71 \\
\hline
\end{tabular}

In general, the strains GI.3, GI.5 and GII.1 stood out in relation to the others due to the potential to reduce the cycle, showing estimates of negative GCA parameters in all places where the experiments were conducted. They are promising regarding their use as parents in breeding programs, with potential in the formation of base populations for the extraction of new strains and have favorable aspects to be explored in hybrid combinations.

The GI.6 strain showed positive estimates of GCA in all environments, which suggests its contribution towards increasing the cycle at the crosses in which it participates. This characteristic is appropriate in situations of a favorable environment for the crop, considering that genotypes of longer cycle generally have greater production potential
(SANTOS; CASELA; WAQUIL, 2005; ROONEY, 2012). These results are important for directing grain sorghum breeding programs, as flowering is a character that is subject to environmental variations (ZANATTO et al., 2016).

Strains that reduce the cycle of hybrids are preferred, since sorghum is planted in the second season with risk of water stress in post-flowering. Super-early hybrids escape the water stress that normally occurs in July in the Cerrado region (BATISTA et al., 2019). In cases of sowing earlier, until the first half of February, it is possible to opt for later hybrids, but after this date super-early hybrids are more competitive.

The market requirement for grain sorghum in relation to plant height is 1.00 to $1.50 \mathrm{~m}$, as plants 
below this range have lower grain yield, whereas taller plants may be susceptible to lodging (SANTOS; CASELA; WAQUIL, 2005; MENEZES et al., 2014). In the selection of grain sorghum strains to be used in the hybridization process, priority is given to those that contribute little or nothing to increase or decrease the heights of hybrids in which they participate (MENEZES et al., 2017). When two strains of grain sorghum are crossed, even though there is no height complement by the four main genes that control the character, the resulting hybrid is almost always taller than the parental lines due to the hybrid vigor of the interaction of smaller genes (ROONEY, 2004; MENEZES et al., 2017).

The strains that most contributed to increase the size of their hybrids in group I were GI.4 in all environments, GI.5 in Rio Verde, Sete Lagoas and Sinop, and GI.6 in Sete Lagoas, Sinop and Teresina. Those in group II were GII.1 and GII.3 in Rio Verde,
Sete Lagoas and Sinop, and GII.4 in Sinop and Teresina (Table 3 ). The strains that caused reduction in plant height in group I were GI.1 and GI.3 in all environments, GI.2 in Sete Lagoas, Sinop and Teresina, and GI.6 in Rio Verde. Group II included GII.1 in Teresina, GII.2 in Sinop, and GII.5 in all environments (Table 3 ).

It appears that the genetic actions that determine the development of the sorghum plant were also influenced by the environment. It is noteworthy that parents that systematically contribute towards considerably increasing or reducing the height of sorghum plants, with the risk of generating hybrids whose height exceeds the values that meet technical recommendations, are not desired. Thus, the parents with lower GCA estimates and thus with little or no contribution to increasing or reducing the plant height were GI.3 and GII.2 (Table 3).

Table 3. Estimates of the general combining ability (GCA) of groups I and II (gi and gj) for plant height, in 30 hybrid combinations resulting from partial diallel crossing, in Rio Verde-GO, Sete Lagoas-MG, Sinop-MT and Teresina-PI.

\begin{tabular}{|c|c|c|c|c|c|}
\hline Parents & Rio Verde & Sete Lagoas & Sinop & Teresina & Averages \\
\hline \multicolumn{6}{|c|}{ GI - Fertility-restorer male parents (Strain R) } \\
\hline GI.1 & $-8,15$ & $-17,30$ & $-14,04$ & $-5,45$ & $-11,24$ \\
\hline GI.2 & -0.87 & -7.10 & -2.90 & -3.89 & -3.69 \\
\hline GI.3 & -4.89 & -3.90 & -2.30 & -1.43 & -3.13 \\
\hline GI.4 & 3.81 & 6.42 & 3.68 & 4.43 & 4.58 \\
\hline GI.5 & 11.77 & 14.60 & 6.90 & 0.65 & 8.48 \\
\hline GI.6 & -1.69 & 7.28 & 8.68 & 5.71 & 4.99 \\
\hline \multicolumn{6}{|c|}{ GII - Male-sterile female parents (Strain A) } \\
\hline GII.1 & 5.34 & 7.66 & 1.75 & -1.07 & 3.42 \\
\hline GII.2 & 0.76 & 0.18 & -2.37 & -0.23 & -0.42 \\
\hline GII.3 & 1.79 & 2.23 & 7.30 & -0.63 & 2.67 \\
\hline GII.4 & -0.97 & -0.67 & 4.30 & 8.17 & 2.71 \\
\hline GII.5 & -6.92 & -9.40 & -10.97 & -6.23 & -8.38 \\
\hline
\end{tabular}

Grain yield is relatively influenced by plant height. Menezes et al. (2017) reported that all strains that contributed to increase the height of the hybrids were the same ones that promoted higher grain yield. Similar behavior was observed in strains GII.1 and GII.3, which influenced the increase in plant height and grain yield. However, the strains GI.1 and GI.2, despite having contributed to the reduction of plant height, in all environments, resulted in the increase of grain yield in all environments; as the strain GII.2, which had little influence on plant height, it also resulted in the increase in grain yield (Table 4).
The restorative strains with superior results for grain yield were GI.1 and GI.2 in all environments and GI.6 in Sete Lagoas and Sinop. In the group of male-sterile strains, the best ones were GII.1, GII.2 and GII.4, also in all environments, unlike the other strains of the two groups, which had negative estimates of general combining ability, leading to the reduction of grain yield (Table 4). The strains with positive GCA estimates indicate an increase in allele and genotypic frequencies for grain yield, being promising for use in breeding programs, in the formation of base populations for the extraction of promising homozygous strains. 
Table 4. Estimates of the general combining ability (GCA) of groups I and II (gi and gj) for grain yield, in 30 hybrid combinations resulting from partial diallel crossing, in Rio Verde-GO, Sete Lagoas-MG, Sinop-MT and Teresina-PI.

\begin{tabular}{cccccc}
\hline Parents & Rio Verde & Sete Lagoas & Sinop & Teresina & Averages \\
\hline GI.1 & & GI - Fertility-restorer male parents (Strain R) & & 0.92 & 0.66 \\
GI.2 & 0.86 & 0.03 & 0.85 & 0.66 & 0.67 \\
GI.3 & 0.94 & 0.69 & 0.41 & -0.10 & -0.31 \\
GI.4 & -0.50 & -0.33 & -0.29 & -0.94 & -0.79 \\
GI.5 & -0.44 & -0.87 & -0.91 & -0.24 & -0.34 \\
GI.6 & -0.32 & 0.01 & -0.79 & -0.30 & 0.10 \\
\hline & -0.52 & 0.49 & 0.75 & & 0.47 \\
GII.1 & 0.29 & GII - Male-sterile female parents (Strain A) & 0.38 & 0.19 \\
GII.2 & 0.43 & 0.94 & 0.24 & 0.22 & -0.06 \\
GII.3 & -0.22 & 0.06 & 0.04 & -0.32 & 0.45 \\
GII.4 & 0.51 & 0.18 & 0.14 & 0.28 & -1.04 \\
GII.5 & -1.01 & 0.29 & 0.69 & -0.57 & -1.12 \\
\hline
\end{tabular}

Strains GI.3, GI.5 and GII.1 for flowering, GI.1, GI.2, GI.3 and GII.5 for plant height, and GI.1, GI.2, GII.1, GII.2 and GII.4 for yield were the ones that had the best GCA estimates in all environments with a predominance of additive effects. The biggest highlights in at least two characteristics were the lines GI.3 for flowering and plant height, GI.1, GI.2 for plant height and grain yield and GII.1 for flowering and yield. These results suggest that these strains are promising in the formation of compounds or synthetic populations aiming at the extraction of homozygous strains.
Strains with low yield are discarded from the breeding program. Those with high grain yield, but with height above $1.5 \mathrm{~m}$, although discarded for direct use in the production of hybrids, can be used in populations to take advantage of this yield. The most favorable crossing is the one with the highest estimate of SCA and at least one of the parents has a high GCA (CRUZ; CARNEIRO, REGAZZI, 2014). Negative estimates of SCA in some hybrid combinations indicate dominance, in order to reduce the number of days to flowering, favoring the earliness of hybrids (Table 5).

Table 5. Estimates of specific combining ability (sij) for days to flowering, of 30 hybrid combinations resulting from partial diallel crossing, in Rio Verde-GO (RV), Sete Lagoas-MG (SL), Sinop-MT (SI) and Teresina-PI (TE), 2017.

\begin{tabular}{cccccccccc}
\hline Hybrids & RV & SL & SI & TE & Hybrids & RV & SL & SI & TE \\
\hline GI.1xGII.1 & -0.35 & 0.61 & 1.16 & 0.24 & GI.4xGII.1 & 2.03 & 2.39 & 0.10 & -0.64 \\
GI.1xGII.2 & 0.75 & -0.14 & -0.14 & -0.49 & GI.4xGII.2 & -0.17 & 0.04 & -0.20 & 0.53 \\
GI.1xGII.3 & -0.40 & 1.06 & -0.41 & 1.94 & GI.4xGII.3 & 1.38 & -0.46 & 0.83 & 0.06 \\
GI.1xGII.4 & 1.06 & -0.01 & 1.41 & 0.68 & GI.4xGII.4 & -0.56 & -0.53 & -3.65 & -1.50 \\
GI.1xGII.5 & -1.05 & -1.51 & -2.02 & -2.37 & GI.4xGII.5 & -2.67 & -1.43 & 2.92 & 1.55 \\
GI.2xGII.1 & 1.57 & 1.77 & 0.98 & 1.50 & GI.5xGII.1 & -0.57 & 1.13 & -1.26 & 0.26 \\
GI.2xGII.2 & 0.67 & 1.42 & -0.02 & 0.77 & GI.5xGII.2 & -0.77 & -2.92 & -1.66 & -1.17 \\
GI.2xGII.3 & 0.22 & 1.62 & -0.29 & -1.80 & GI.5xGII.3 & -3.22 & -2.72 & -0.53 & -2.34 \\
GI.2xGII.4 & -0.02 & -2.15 & 0.23 & 0.64 & GI.5xGII.4 & -0.16 & 3.81 & 1.99 & 0.60 \\
GI.2xGII.5 & -2.43 & -2.65 & -0.90 & -1.11 & GI.5xGII.5 & 4.73 & 0.71 & 1.46 & 2.65 \\
GI.3xGII.1 & -2.21 & -3.39 & 0.36 & -0.46 & GI.6xGII.1 & -0.45 & -2.49 & -1.34 & -0.92 \\
GI.3xGII.2 & 0.89 & 1.16 & 0.46 & 1.91 & GI.6xGII.2 & -1.35 & 0.46 & 1.56 & -1.55 \\
GI.3xGII.3 & -1.16 & -1.24 & 0.09 & -1.16 & GI.6xGII.3 & 3.20 & 1.76 & 0.29 & 3.28 \\
GI.3xGII.4 & -0.70 & -1.01 & 0.91 & 1.58 & GI.6xGII.4 & 0.36 & -0.11 & -0.89 & -1.98 \\
GI.3xGII.5 & 3.19 & 4.49 & -1.82 & -1.87 & GI.6xGII.5 & -1.75 & 0.39 & 0.38 & 1.17 \\
\hline
\end{tabular}


The crossings that contributed to the reduction of the cycle in all environments were GI.1xGII.5, GI.2xGII.5, GI.4xGII.4, GI.5xGII.2, GI.5xGII.3 and GI.6xGII.1, highlighting those that contain parental GI.5 and GII.1, which had negative GCA in all environments. The earliness of the hybrid is desired in situations where there is a risk of water stress due to the time of sowing, a recurring situation in succession crops of soybean. Thus, these genotypes have favorable aspects in the formation of hybrids of shorter cycles, as well as in the formation of populations for the extraction of new strains.

In the opposite direction, the crossings GI.2xGII.1, GI.3xGII.2, GI.5xGII.5 and GI.6xGII.3 had positive estimates of SCA in all environments, emphasizing the presence in one of these of the parental GI. 6, which had positive GCA in all environments. Therefore, these genotypes have the potential to generate hybrids of longer cycle and populations for the extraction of strains with allele frequency for this characteristic. Longer-cycle hybrids are an option for sowing at times favorable to plant development, with less risk of water stress and are generally associated with higher grain yields (SANTOS; CASELA; WAQUIL, 2005; ROONEY,
2012).

Plant height correlates with grain yield because, in general, shorter hybrids have lower production potential while taller hybrids can have greater susceptibility to lodging, so what is desirable is to be between 1.0 and 1.5 meters (SANTOS; CASELA; WAQUIL, 2005). Therefore, for combining ability, the ideal are those crosses with a SCA estimate close to zero and that have at least one GCA parent that is between the limit of -5 and +5 (MENEZES et al., 2017). Among the crossings performed, GI.1xGII.2, GI.3xGII.2 and GI.3xGII.4 obtained estimates of SCA and at least one parent with GCA within these limits (Table 6).

The hybrid combinations that had undesirable SCA estimates in all environments and with at least one parent with GCA that exceeded the limits in most environments were GI.3xGII.5 and GI.5xGII.4, with a tendency to drastically reduce plant size, and GI.5xGII.5 and GI.6xGII.4 with a tendency to considerably increase plant size (Table 6). These hybrid combinations should be avoided in breeding programs, as they may generate genotypes with unsatisfactory characteristics in relation to the desired height for the crop.

Table 6. Estimates of the specific combining ability (sij) for plant height, of 30 hybrid combinations resulting from partial diallel crossing, in Rio Verde-GO (RV), Sete Lagoas-MG (SL), Sinop-MT (SI) and Teresina-PI (TE), 2017.

\begin{tabular}{cccccccccc}
\hline Hybrids & RV & SL & SI & TE & Hybrids & RV & SL & SI & TE \\
\hline GI.1xGII.1 & 0.50 & -0.68 & 0.99 & 0.99 & GI.4xGII.1 & 0.44 & -0.20 & -3.43 & -4.29 \\
GI.1xGII.2 & -3.12 & -4.00 & -2.89 & -0.05 & GI.4xGII.2 & -3.98 & 3.08 & 5.39 & 2.87 \\
GI.1xGII.3 & 3.75 & -3.55 & 1.74 & 0.05 & GI.4xGII.3 & -2.71 & -7.27 & 0.02 & -2.23 \\
GI.1xGII.4 & -2.29 & 0.15 & -0.26 & 2.05 & GI.4xGI.4 & 3.15 & 1.43 & -9.28 & 1.87 \\
GI.1xGII.5 & 1.16 & 8.08 & 0.41 & -3.05 & GI.4xGII.5 & 3.10 & 2.96 & 7.29 & 1.77 \\
GI.2xGII.1 & 4.62 & 1.62 & -2.45 & 6.03 & GI.5xGII.1 & -1.42 & 8.32 & -1.95 & 0.39 \\
GI.2xGII.2 & 7.20 & 0.00 & -6.03 & 6.19 & GI.5xGII.2 & 4.46 & -0.90 & 5.17 & -3.65 \\
GI.2xGII.3 & -6.23 & 5.45 & 6.30 & 0.59 & GI.5xGII.3 & -4.67 & -7.95 & -2.50 & -1.45 \\
GI.2xGII.4 & 0.73 & -1.65 & -0.40 & -7.51 & GI.5xGII.4 & -10.81 & -13.95 & -11.20 & -8.85 \\
GI.2xGII.5 & -6.32 & -5.42 & 2.57 & -5.31 & GI.5xGII.5 & 12.44 & 14.48 & 10.47 & 13.55 \\
GI.3xGII.1 & -0.46 & 5.92 & 17.25 & 1.57 & GI.6xGII.1 & -3.66 & -14.96 & -10.43 & -4.67 \\
GI.3xGII.2 & 4.12 & 3.70 & 4.67 & 1.63 & GI.6xGII.2 & -8.68 & -1.88 & -6.31 & -7.01 \\
GI.3xGII.3 & 5.79 & 7.25 & -0.30 & 3.03 & GI.6xGII.3 & 4.09 & 6.07 & -5.28 & -0.01 \\
GI.3xGII.4 & 3.85 & 1.75 & 1.40 & 3.03 & GI.6xGII.4 & 5.35 & 12.27 & 19.72 & 9.39 \\
GI.3xGII.5 & -13.30 & -18.62 & -23.03 & -9.27 & GI.6xGII.5 & 2.90 & -1.50 & 2.29 & 2.29 \\
\hline
\end{tabular}

Estimates of SCA for grain yield have relevant significance, mainly in breeding programs with emphasis on the development of hybrids, since they are measures of non-additive gene effects, such as dominance and epistasis effects, which determine the magnitude of heterosis (CRUZ; CARNEIRO;
REGAZZI, 2014).

The hybrid combinations with positive SCA estimates for grain yield in most environments were GI.1xGII.1, GI.1xGII.2, GI.3xGII.2 and GI.5xGII.1 in Rio Verde, Sete Lagoas and Sinop; GI.2x GII.2 and GI.2x GII.5 in Rio Verde, Sinop and Teresina, 
GI.2x GII.3 in Rio Verde, Sete Lagoas and Teresina, GI.3x GII.1 and GI.5x GII.2 in Sete Lagoas, Sinop and Teresina. It is noteworthy that these combinations had at least one parent with positive GCA for grain yield in all environments. This highlights the relevance of studies in different environments to determine potential hybrid combinations for specific regions.

The grain yield characteristic is highly influenced by the environment; thus, estimates of GCA and SCA are more accurate when they come from experiments conducted in various environments, ensuring greater reliability in the selection of parents to partake in hybridization programs. In this context, it is possible to highlight the crossings GI.1xGII.1, GI.3xGII.4, GI.4xGII.5, GI.5xGII.3 and GI.6xGII.5 with positive SCA estimates in all environments; however, only the crosses GI.1xGII.1 and GI.3xGII.4 showed parental GI.1 and GII.4 with positive GCA estimates in all environments (Table 7).

The association of favorable aspects of characters of agronomic interest in a hybrid is important, especially considering the need to meet farmers' demands. The hybrid combination GI.5xGII.3 had estimates of SCA and GCA in order to reduce days to flowering and contribute to a significant increase in grain yield. However, the SCA estimates for plant height indicate an effect on the reduction of size, which is somewhat preferable in the cultivation of grain sorghum to the detriment of tall plants, since they do not negatively influence grain yield, which was not the case of this hybrid.

The hybrid combination GI.1xGII.2, despite having negative GCA estimates for plant height, is within the range from -5 to +5 , which in a way does not cause a drastic reduction in size; moreover, it had favorable SCA estimate and at least one parent with positive GCA for grain yield in all environments. This hybrid showed negative SCA estimates for days to flowering in three environments (Sete Lagoas, Sinop and Teresina), and has favorable aspects in more than one characteristic, standing out as promising to be used in tests in the evaluation network.

Table 7. Estimates of specific combining ability (sij) for grain yield, of 30 hybrid combinations resulting from partial diallel crossing, in Rio Verde-GO (RV), Sete Lagoas-MG (SL), Sinop-MT (SI) and Teresina-PI (TE), 2017.

\begin{tabular}{cccccccccc}
\hline Hybrids & RV & SL & SI & TE & Hybrids & RV & SL & SI & TE \\
\hline GI.1xGII.1 & 0.83 & 0.26 & 0.14 & 0.00 & GI.4xGII.1 & -0.77 & -1.04 & -0.70 & -0.54 \\
GI.1xGII.2 & 0.89 & 0.24 & 0.04 & -0.54 & GI.4xGII.2 & -0.41 & -0.66 & -0.60 & -0.18 \\
GI.1xGII.3 & -0.86 & -0.48 & -0.06 & -0.20 & GI.4xGII.3 & -0.86 & -0.28 & -0.30 & -0.04 \\
GI.1xGII.4 & -0.59 & -0.49 & -0.01 & 0.90 & GI.4xGII.4 & 0.61 & -0.39 & -0.75 & -0.74 \\
GI.1xGII.5 & -0.27 & 0.47 & -0.10 & -0.15 & GI.4xGII.5 & 1.43 & 2.37 & 2.36 & 1.51 \\
GI.2xGII.1 & -0.45 & 1.40 & 0.28 & 0.16 & GI.5xGII.1 & 0.81 & 0.48 & 0.58 & -0.44 \\
GI.2xGII.2 & 0.41 & -0.72 & 0.08 & 0.22 & GI.5xGII.2 & -0.03 & 1.06 & 0.18 & 0.82 \\
GI.2xGII.3 & 0.46 & 0.26 & -0.92 & 0.26 & GI.5xGII.3 & 1.22 & 0.84 & 0.08 & 1.16 \\
GI.2xGII.4 & -0.67 & -0.85 & 0.23 & -1.04 & GI.5xGII.4 & -0.21 & -0.27 & 0.43 & -0.04 \\
GI.2xGII.5 & 0.25 & -0.09 & 0.34 & 0.41 & GI.5xGII.5 & -1.79 & -2.11 & -1.26 & -1.49 \\
GI.3xGII.1 & -0.61 & 0.32 & 0.38 & 0.92 & GI.6xGII.1 & 0.21 & -1.40 & -0.66 & -0.08 \\
GI.3xGII.2 & 0.05 & 0.30 & 0.58 & -0.12 & GI.6xGII.2 & -0.93 & -0.22 & -0.26 & -0.22 \\
GI.3xGII.3 & -0.30 & 0.08 & 0.58 & -0.68 & GI.6xGII.3 & 0.32 & -0.44 & 0.64 & -0.48 \\
GI.3xGII.4 & 1.17 & 0.77 & 0.23 & 0.62 & GI.6xGII.4 & -0.31 & 1.25 & -0.11 & 0.32 \\
GI.3xGII.5 & -0.31 & -1.47 & -1.76 & -0.73 & GI.6xGII.5 & 0.71 & 0.81 & 0.40 & 0.47 \\
\hline
\end{tabular}

\section{CONCLUSIONS}

There was a significant effect of the GCA of the restorer strains for all the characteristics evaluated and for the male-sterile strains in their majority, with importance of the additive and nonadditive effects in the control of the evaluated characters. The strains GI.1, GI.2, GII.1 and GII.4 were the ones that most contributed to increase grain yield in the hybrids in which they participated. The hybrid combinations GI.5xGII.3 and GI.1xGII.2 stood out for having the potential to reach high averages for grain yield, associating favorable aspects in the other characteristics. 


\section{ACKNOWLEDGEMENTS}

Thanks to the Coordenação de Aperfeiçoamento de Pessoal de Nível Superior (CAPES), the Conselho Nacional de Desenvolvimento Científico e Tecnológico, and to the Fundação de Amparo à Pesquisa do Estado de Goiás (FAPEG), for the financial support.

\section{REFERENCES}

ALMEIDA FILHO, J. E. et al. Desempenho agronômico e estabilidade fenotípica de híbridos de sorgo granífero. Revista Brasileira de Milho e Sorgo, 9: 51-64, 2010.

BANZATTO, D. A.; KRONKA, S. N. Experimentação Agrícola. 4. ed. Jaboticabal, SP: FUNEP, 2006. 237 p.

BATISTA, P. S. C. et al. Selection of sorghum for drought tolerance in a semiarid environment. Genetics and Molecular Research, 18: 01-11, 2019.

COMPANHIA NACIONAL

DE ABASTECIMENTO - CONAB. Acompanhamento da Safra Brasileira de Grãos: $11^{\circ}$ levantamento, safra 2018/19. v. 6, n. 11. Brasília, DF: Conab, 2019.

CRUZ, C. D.; CARNEIRO, P. C. S.; REGAZZI, A. J. Modelos biométricos aplicados ao melhoramento genético. 3. ed. rev. e ampl. Viçosa, MG: UFV, 2014. 668 p.

EMPRESA BRASILEIRA DE PESQUISA AGROPECUÁRIA - EMBRAPA. Sistema Brasileiro de Classificação de Solos. 3. ed. Rio de Janeiro, RJ: EMBRAPA, 2013. 353 p.

GRIFFING, B. Concept of general and specific combining ability in relation to diallel crossing systems. Australian Journal of Biological Sciences, 9: 463-493, 1956.

KENGA, R.; ALABI, S. O.; GUPTA, S. C. Combining ability studies in tropical sorghum (Sorghum bicolor (L.) Moench). Field Crops Research, 88: 251-260. 2004.

KUMAR, A. A. et al. Recent advances in sorghum genetic enhancement research at ICRISAT. American Journal of Plant Sciences, 2: 589-600, 2011.

MAHDY, E. E; ALI, M. A; MAHMOUD, A. M. The effect of environment on combining ability and heterosis in grain sorghum (Sorghum bicolor L. Moench). Asian Journal of Crop Science, 3: 1-15, 2011 .

MAKANDA, I. et al. Combining ability and cultivar superiority of sorghum germplasm for grain yield across tropical low- and mid-altitude environments. Field Crops Research, 116: 75-85, 2010.

MENEZES, C. B. et al. Combining ability of grain sorghum lines selected for aluminum tolerance. Crop Breeding and Applied Biotechnology, 14: 42 $-48,2014$.

MENEZES, C. B et al. Capacidade combinatória de linhagens e seleção de híbridos de sorgo granífero. Revista Brasileira de Milho e Sorgo, 16: 509-523, 2017.

PRAKASH, R. et al. Combining ability for fodder yield and its components in Sorghum (Sorghum bicolor L). Electronic Journal of Plant Breeding, 1: 124-128, 2010.

ROONEY, W. L. Sorghum improvement integrating traditional and new technology to produce improved genotypes. Advances in Agronomy, 83: 37-109, 2004

ROONEY, W. Sorghum breeding. In: ACQUAAH, G. (Ed.). Principles of plant genetics and breeding. 2. ed. Chichester: Wiley-Blackwell, 2012. cap. 34, p. 617-627.

SANTOS, F. G.; CASELA, C. R.; WAQUIL, J. M. Melhoramento de sorgo. In: BORÉM, A. (Ed.). Melhoramento de espécies cultivadas. 2. ed. Viçosa, MG: UFV, 2005. v. 1, p. 429-466.

TADESSE, T.; TESSO, T.; EJETA, G. Combining ability of introduced sorghum parental lines for major morpho-agronomic traits. SAT eJournal, 6: 1 $-7,2008$

TARDIN, F. D. et al. Avaliação agronômica de híbridos de sorgo granífero cultivados sob irrigação e estresse hídrico. Revista Brasileira de Milho e Sorgo, 12: 102-117, 2013

VENCOVSKY, R.; BARRIGA, P. Genética biométrica no fitomelhoramento. 1. ed. Ribeirão Preto, SP: SBG, 1992. 496 p.

ZANATTO, I. B. et al. Identificação de caracteres relacionados à precocidade e produtividade em híbridos de sorgo via correlações canônicas. Revista Científica Intelletto, 1: 89-94, 2016. 